\title{
Catecholamine-Induced Cardiomyopathy - a Clinical Case
}

\author{
Ludmila Vladimirova-Kitova ${ }^{1,2}$, Spas Kitov², Petar Uchikov²,3, George Pavlover, \\ ${ }^{1}$ Section of Cardiology, First Department of Internal Diseases, Medical University of Plovdiv, Plovdiv, Bulgaria \\ ${ }^{2}$ St George University Hospital, Plovdiv, Bulgaria \\ ${ }^{3}$ Department of Special Surgery, Faculty of Medicine, Medical University of Plovdiv, Plovdiv, Bulgaria \\ ${ }^{4}$ Department of Anaesthesiology, Emergency, and Intensive Care Medicine, Faculty of Medicine, Medical University of Plovdiv, Plovdiv, Bulgaria
}

Corresponding author: Ludmila Vladimirova-Kitova, First Section of Cardiology, Department of Internal Diseases, Medical University of Plovdiv, St George University Hospital, Plovdiv, Bulgaria; E-mail: kitov@vip.bg; Tel.: +359 888428255

Received: 16 Jan 2021 Accepted: 21 Apr 2021 Published: 28 Feb 2022

Citation: Vladimirova-Kitova L, Kitov S, Uchikov P, Pavlov G. Catecholamine-induced cardiomyopathy - a clinical case. Folia Med (Plovdiv) 2022;64(1):156-61. doi: 10.3897/folmed.64.e63215.

\begin{abstract}
A 27-year-old patient presented with a 3-month history of episodic headaches and persistently rising blood pressure (up to 240/120). The clinical, laboratory, and instrumental findings (episodes of severe hypertension, increased levels of metanephrine in urine, and MRI showing a mass of $5.1 \times 5.5 \mathrm{~cm}$ in diameter) led us to the diagnosis of pheochromocytoma of the right adrenal grand. Preoperative medication included alpha blockers, calcium channel blockers, and plasma. The right adrenal gland was completely removed using the retroperitoneal access. During the extraction of the tumour, a ventricular tachycardia was recorded after which acute heart failure issued. In the first few hours, echocardiographic imaging showed a reduced EF of $9 \%$ - catecholamine-induced cardiomyopathy. The patient underwent a complex and adequate reanimation in the intensive care unit which lasted 20 days. A slow but steady increase in the ejection fraction along with a decrease in congestion was observed. Magnetic resonance imaging was used to confirm the normalisation of myocardial morphology. A German histological laboratory was used to confirm the benign form of the tumour. For the next three months, the patient was on a standard therapy with beta blockers, angiotensin-converting-enzyme inhibitor and mineralocorticoid antagonists. The catecholamine surge during the removal of a large pheochromocytoma could lead to severe cardio-vascular complication, even with a complete and adequate preoperative protective medication. The reversibility of the process implies the necessity of an adequate and timely postoperative treatment for a complete involution of the pathomorphological changes.
\end{abstract}

\section{Keywords}

catecholamine-induced cardiomyopathy, pheochromocytoma, postoperative complications

\section{INTRODUCTION}

Pheochromocytoma is a sporadic, or in some cases, hereditary neuroendocrine tumour. ${ }^{1}$ Since the first successful resection of pheochromocytoma in 1926, many studies have focused on the perioperative management of this surgery. ${ }^{2-8}$ For a long time, this surgery has been considered to be quite a challenge in regards to morbidity and mortality caused by adrenergic discharges. Catecholamine-induced cardiomyopathy in the setting of operation for pheochro- mocytoma is an unusual clinical entity. Metabolites of catecholamines have been thought to have a direct toxic effect on the myocardium. Catecholamine induced vasoconstriction, a direct toxic effect of catecholamine degradation and direct receptor-mediated mechanisms are thought to contribute to cardiomyopathy in subjects with pheochromocytoma. The links between hemodynamic instability and high morbimortality have been established since the 1950s. ${ }^{9}$ To avoid postoperative complications a patient must undergo an adequate preoperative pharmacological preparation.

Copyright by authors. This is an open access article distributed under the terms of the Creative Commons Attribution License (CC-BY 4.0), 
The preoperative pharmacological preparation has reduced the morbimortality in the last decades. ${ }^{10}$ The classically recommended preoperative pharmacological preparation includes alpha-blockers given 7-14 days before surgery and cardioselective beta-blockers 3 days before surgery in case of tachycardia. ${ }^{11}$ The use of calcium channels blockers as preoperative pharmacological preparation is favoured by some teams. ${ }^{12}$ This is still strongly debated especially in highly experienced surgical-anesthesiology teams where a more individualized approach is sometimes preferred. ${ }^{13}$ Morbidity in pheochromocytoma surgeries remains high (10.7 to $29.8 \%$ ) even with significant advances in imaging and genetics as well as surgical anesthetics. ${ }^{14,15}$

\section{CASE REPORT}

The case report is about a 27-year-old woman who, for the last three months, suffered from headaches and recurrent hypertensive crises (up to 240/120) which were associated with increased abdominal pressure during activities such as lifting her child. The hypertensive crises were every 3-4 days. 24-hour blood pressure monitoring did not show any abnormalities. After her last consultation with her general practitioner, the patient was referred to a psychiatrist. After a consecutive cardiological examination, an analysis of urine metanephrine was scheduled which came back extremely elevated. Renin, aldosterone, and cortisol were within normal range. Computed tomography scan showed a large suspicious mass in the right adrenal gland. Subsequent magnet$i c$ resonance imaging revealed a tumour in the right adrenal gland with a diameter of $5.1 \times 5.5 \mathrm{~cm}$ (Fig. 1). ${ }^{16,17}$

Preoperative medication strictly followed the guideline requirements. The patient, prior to the operation, was on low-to-moderate doses of alpha blockers for two weeks. Due to intolerance, characterised by extreme hypotension, the patient found it difficult to continue the antihypertensive therapy. In contrast to the intolerance, she had frequent hypertensive crises every 3-4 days which made postponing the operation, in view of the holidays, quite impossible. The operation was performed with due haste - open surgery. Under general anesthesia and with a retroperitoneal access the entire right adrenal gland was removed. During the removal, the patient suffered a hypertensive crisis, ventricular tachycardia and within the following hours - progressive heart failure. All complications developed during an infusion of nitroprusside sodium (Nitropress) and plasma. The echocardiography examination showed global hypokinesia with severely reduced ejection fraction (no takotsubo-like changes - dyskinetic apical and midventricular segments with concomitant hyperkinetic basal segments) - EF of up to 9\% within the first hour - catecholamine induced cardiomyopathy. ${ }^{19}$ The ECG showed abnormalities like an acute coronary syndrome, but without troponin elevation in this case (Fig. 2).

In the intensive care unit, the patient underwent an adequate and complex reanimation with dopamine and Dobutrex. For 20 days, a slow but steady increase in the myo-

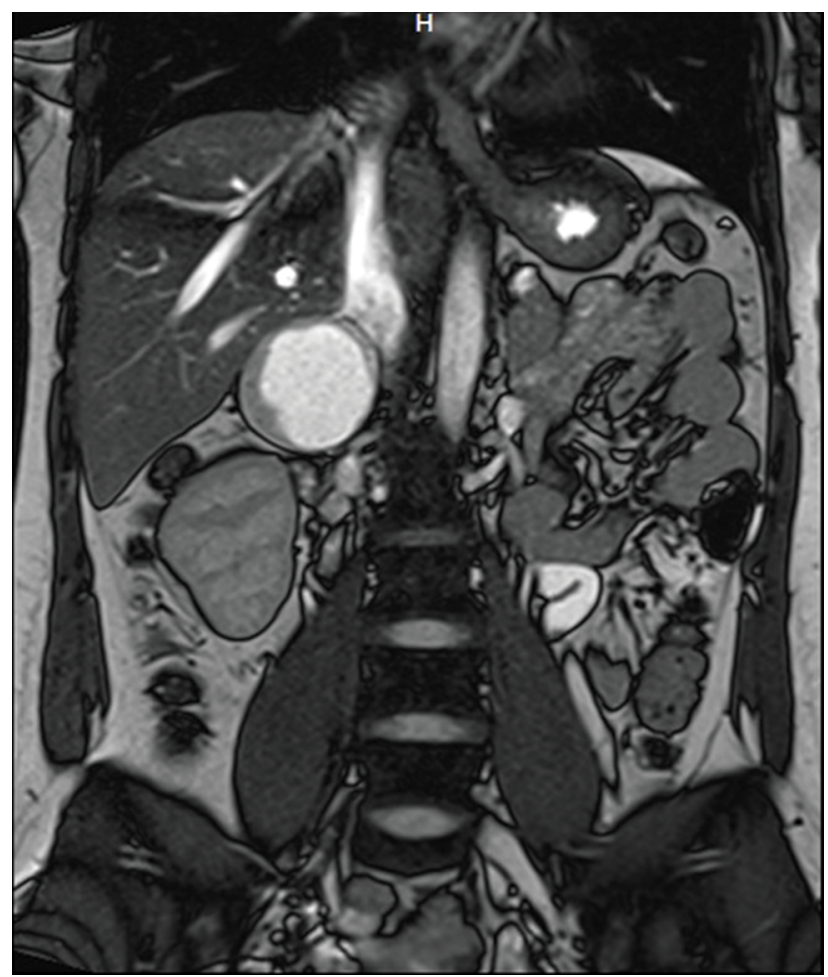

Figure 1. A well formed heterogenous lesion $(5.1 \times 5.5 \mathrm{~cm})$ can be seen in the right adrenal gland.

cardial ejection function was observed with a decrease of the congestion. A daily monitoring of the cardiac function was performed which included ejection fraction. A slow increase in EF was monitored - 30\% $\rightarrow 37 \% \rightarrow 41 \% \rightarrow 55 \%$.

Measuring left ventricle deformation with global longitudinal strain-mean showed a more precise change when comparing the initial -10 days $(-11 \%)$ and the measurements at 20 days - an almost global (-20\%) recovery of the left ventricle myocardial kinetics (Fig. 3).

Complete recovery of the $L V$ function was observed at 8 weeks. The result was confirmed with the use of cardiac magnetic resonance imaging at 8 weeks, which demonstrated a normal systolic function of the left ventricle and a similar one in the right ventricle, the myocardium showed no structural abnormalities (Fig. 4).

Histological examination of the tumour was done in Germany at the Institute of Pathology in Munich which confirmed a benign variant of a large pheochromocytoma $-5 \mathrm{~cm}$ in diameter without evidence of mitosis, necrosis or infiltration.

Up until the third month, the patient was on a standard medical treatment which included beta blockers, angiotensin-converting-enzyme inhibitor, mineralocorticoid antagonists. Routine follow-up by an endocrinologist 6 months after the operation showed no elevation in metanephrines and normetanephrines in urine. The latter did not require further imaging studies. After the first year after operation, the patient has made a complete clinical recovery with echocardiographic results showing an EF of 70\%. She has recovered her normal quality of life. 
L. Vladimirova-Kitova et al

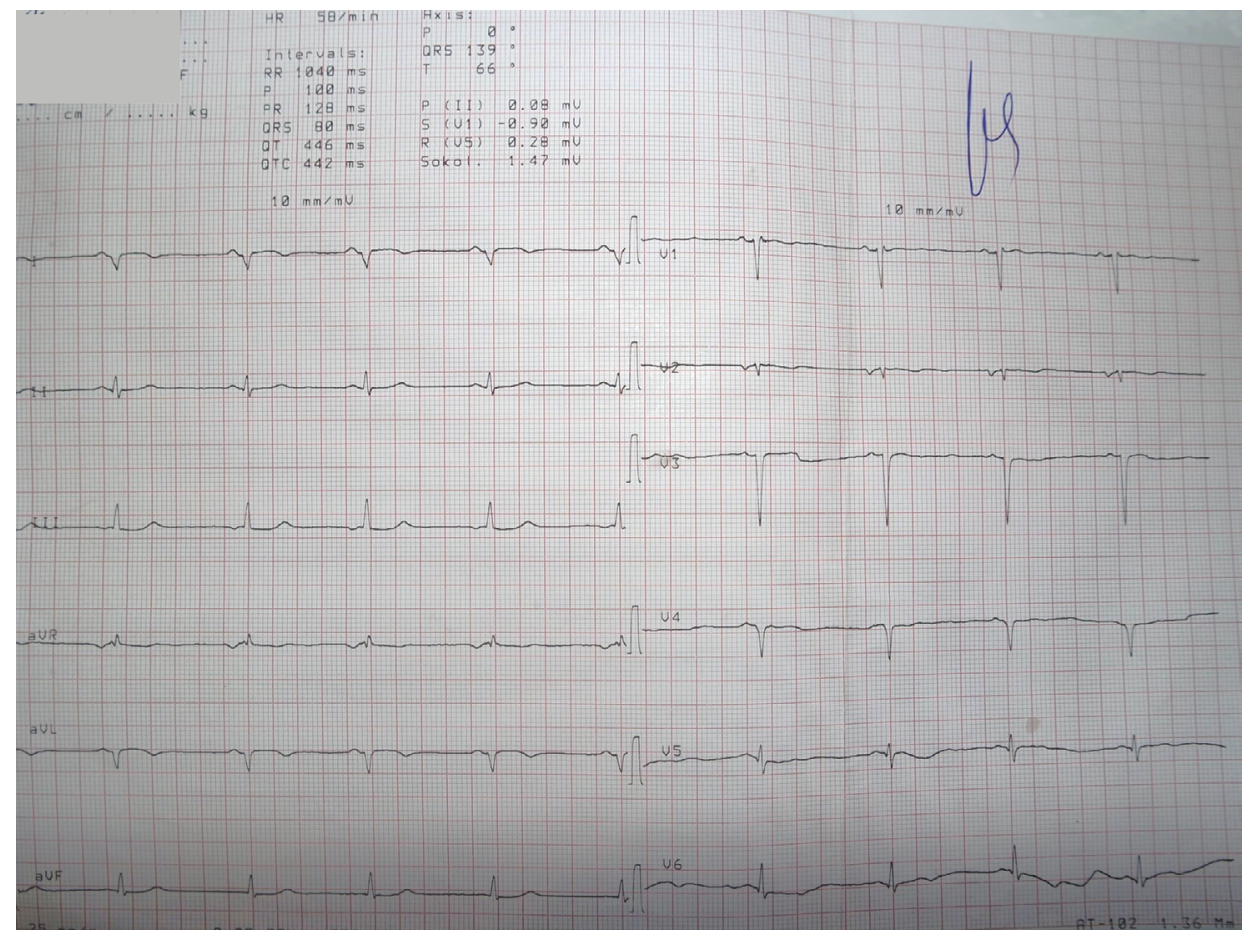

Figure 2. Electrocardiography after operation.

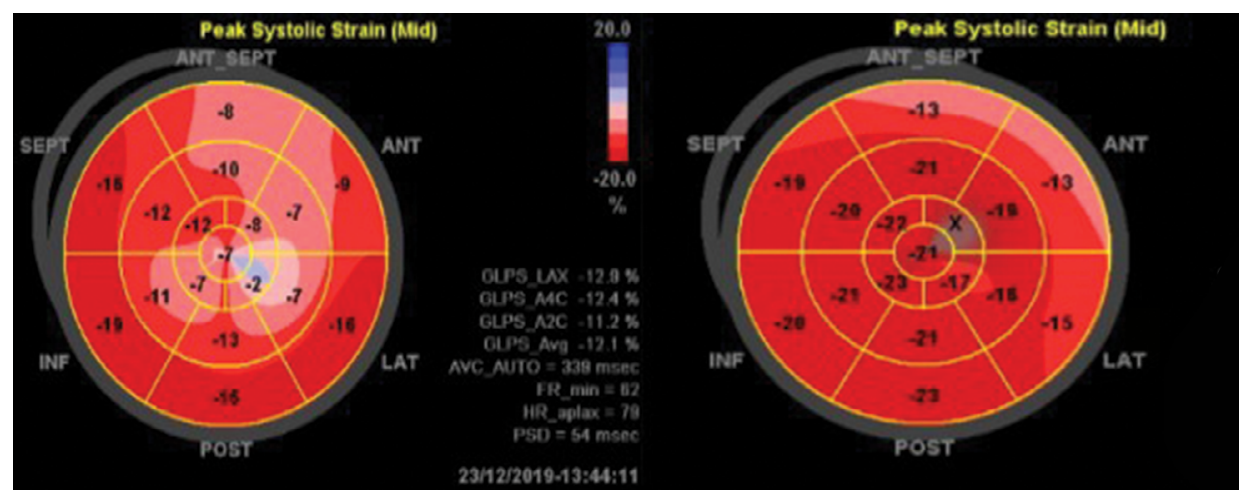

Figure 3. Global longitudinal strain at 10 and 20 days postoperatively - the darker red shows the left ventricle recovery.

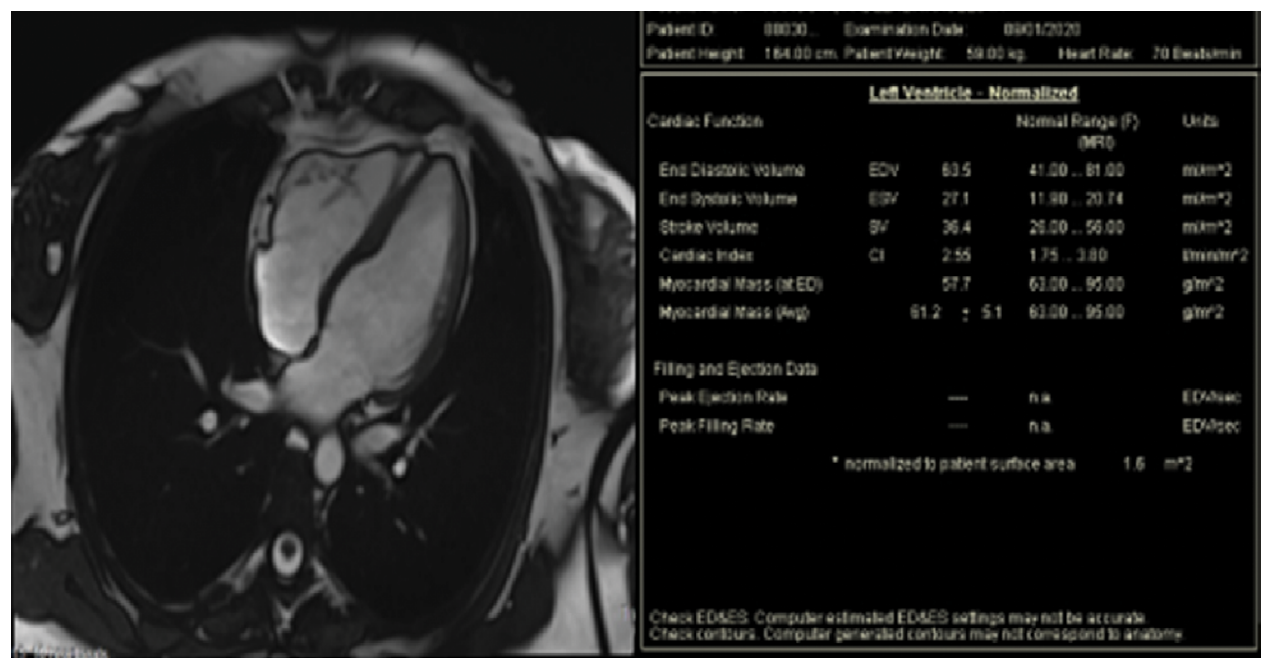

Figure 4. Cardiac magnetic resonance imaging at 30 days postoperatively. 


\section{DISCUSSION}

The presented case confirms the fact that large pheochromocytomas, even with an adequate preoperative preparation, still hold significant risk for the development of cathecholamine-induced cardiomyopathy. The recovery period, after which the myocardium will return to its initial morphology, is around 8 weeks. Similar data can be seen in literature. ${ }^{17,18,20}$

Preoperative antihypertensive medication with monotherapy with alpha blockers (unable to tolerate due to hypertensive crises every few days) and intraoperative infusion of nitroprusside sodium (Nitropress) did not prevent the complication. The large size of the pheochromocytoma was the main reason for the undesired outcome. This correlates with other publications in the literature which determine the postoperative necessity of pressor amines for managing cardiovascular morbidity. ${ }^{21,22}$ Tumour size (along with preoperative beta blockers and/or diuretics) is a predicting factor for the need of pressor amines. ${ }^{22}$

Surgical intervention with open resection was favoured due to the size of the tumour (nearly $6 \mathrm{~cm}$ according to recommendations) along with the complete removal of the right adrenal gland. ${ }^{23,24}$ This access allowed the complete tumour resection, prevented tumour rupture, and avoided local recurrence. ${ }^{6}$ There are no prospective randomized studies comparing laparoscopic with open adrenalectomy for pheochromocytomas. There are no data regarding any difference in recurrence rate after open vs. laparoscopic adrenalectomy. Only a few studies discuss differences between the two methods such as less pain, less blood loss, fewer hospital days, and less surgical morbidity than open adrenalectomy. Also minimally invasive adrenalectomy results have equivalent perioperative outcomes compared to open adrenalectomy. ${ }^{24,25}$

The use of inotropic medication in the setting of a postoperative catecholamine-induced cardiomyopathy is still debated. There are still very few cases that have been described in literature pertaining to takotsubo cardiomyopathy (left ventricular ballooning syndrome) induced during dobutamine stress echocardiography, as well as a report about a fatal case of takotsubo cardiomyopathy that followed a dobutamine stress test. ${ }^{10,11}$ In our patient with a postoperative catecholamine-induced cardiomyopathy, volume compensation was fundamental for the patient reanimation. In the setting of a cardiogenic shock, the usage of inotropic medication for hemodynamic stability was required. Unlike some cases of dobutamine stress echocardiography, there was no worsening in our patients. ${ }^{26,27}$

This case confirms the necessity of an individual approach and a multidisciplinary team for a successful outcome. Cathecholamine induced cardiomyopathy is an acute complication. With a timely and adequate therapeutic approach by a multidisciplinary team (cardiologist, endocrinologist, intensivists, and surgeons) the long term prognosis can be positive.

\section{REFERENCES}

1. Bryant J, Farmer J, Kessler LJ, et al. Pheochromocytoma: the expanding genetic differential diagnosis. J Natl Cancer Inst 2003; 95:1196-204.

2. Frunzac RW, Grant CS. Pheochromocytoma. In: Clark OH, Duh Q-Y, Kebebew E, et al. eds. Textbook of endocrine surgery. Philadelphia: Jaypee Brothers Medical Publishers; 2016;1047-67.

3. Brunaud L, Nguyen-Thi P-L, Mirallie E, et al. Predictive factors for postoperative morbidity after laparoscopic adrenalectomy for pheochromocytoma: a multicenter retrospective analysis in 225 patients. Surg Endosc 2016; 30:1051-9.

4. Bruynzeel H, Feelders RA, Groenland THN, et al. Risk factors for hemodynamic instability during surgery for pheochromocytoma. J Clin Endocrinol Metab 2010; 95:678-85.

5. Lentschener C, Gaujoux S, Tesniere A, et al. Point of controversy: perioperative care of patients undergoing pheochromocytoma removal-time for a reappraisal? Eur J Endocrinol 2011; 165:365-73.

6. Wu S, Chen W, Shen L, et al. Risk factors for prolonged hypotension in patients with pheochromocytoma undergoing laparoscopic adrenalectomy: a single-center retrospective study. Sci Rep 2017; 7:5897.

7. Plouin PF, Duclos JM, Soppelsa F, et al. Factors associated with perioperative morbidity and mortality in patients with pheochromocytoma: analysis of 165 operations at a single center. J Clin Endocrinol Metab 2001; 86:1480-6.

8. Lafont M, Fagour C, Haissaguerre M, et al. Per-operative hemodynamic instability in normotensive patients with incidentally discovered pheochromocytomas. J Clin Endocrinol Metab 2015; 100:417-21.

9. Apgar V, Papper EM. Pheochromocytoma. Anesthetic management during surgical treatment. AMA Arch Surg 1951; 62:634-48.

10. Boutros AR, Bravo EL, Zanettin G, et al. Perioperative management of 63 patients with pheochromocytoma. Cleve Clin J Med 1990; 57:613-7.

11. Lenders JWM, Duh Q-Y, Eisenhofer G, et al. Pheochromocytoma and paraganglioma: an endocrine society clinical practice guideline. J Clin Endocrinol Metab 2014; 99:1915-42.

12. Brunaud L, Boutami M, Nguyen-Thi P-L, et al. Both preoperative alpha and calcium channel blockade impact intraoperative hemodynamic stability similarly in the management of pheochromocytoma. Surgery 2014; 156:1410-17.

13. Isaacs M, Lee P. Preoperative alpha-blockade in phaeochromocytoma and paraganglioma: is it always necessary? Clin Endocrinol (Oxf) 2017; 86:309-14.

14. Gaujoux S, Bonnet S, Lentschener C, et al. Preoperative risk factors of hemodynamic instability during laparoscopic adrenalectomy for pheochromocytoma. Surg Endosc 2016; 30:2984-93.

15. Bai S, Yao Z, Zhu X, et al. Risk factors for postoperative severe morbidity after pheochromocytoma surgery: a single center retrospective analysis of 262 patients. Int J Surg 2018; 60:188-93.

16. Goldstein RE, O'Neill Jr JA, Holcomb GW, et al. Clinical experience over 48 years with pheochromocytoma. Ann Surg 1999; 229(6):755-64.

17. Min D. Catastrophic catecholamine-induced cardiomyopathy rescued by extracorporeal membrane oxygenation in recurrent malignant pheochromocytoma. Yeungnam Univ J Med 2019; 36(3):254-9.

18. Mierke J, Loehn T, Linke A, et al. Reverse takotsubo cardiomyopathy - life-threatening symptom of an incidental pheochromocytoma: a case report. EHJ: Case Reports 2019; 3(4):1-6. 
19. Sedaia E, Esanu A, Ivanov V, et al. Catecholamine-induced cardiomyopathy in a patient with pheochromocytoma and polycystic kidney and liver disease: a case report. EHJ: Case Reports 2019; 3:1-6.

20. Goldstein D, Voigt M, Ruan D. Current preoperative preparation of pheochromocytoma/paraganglioma syndrome. Clin Surg 2017; 2:1517.

21. Lenders JW, Duh Q-Y, Eisenhofer G, et al. Pheochromocytoma and paraganglioma: an endocrine society clinical practice guideline. J Clin Endocrinol Metab 2014; 99(6):1915-42.

22. Buisset C, Guerin C, Cungi P, et al. Pheochromocytoma surgery without systematic preoperative pharmacological preparation: insights from a referral tertiary center experience. Surgical Endoscopy 2021; 35(2):728-35.

23. Patel D, Phay J, Yen T, et al. Update on pheochromocytoma and paraganglioma from the SSO endocrine and head and neck disease site working group, Part 2 of 2: perioperative management and outcomes of pheochromocytoma and paraganglioma. Ann Surg Oncol 2020; 27(5):1338-47.

24. Wang J, Wang Z, Zhu Y, et al. Minimally invasive adrenalectomy results in equivalent perioperative outcomes versus open adrenalectomy for adrenal mass larger than $6 \mathrm{~cm}$ : A retrospective propensity score-matched study. Eur J Surg Oncol 2020; 46(5):839-46.

25. Zhu W, Wang S, Du G, et al. Comparison of retroperitoneal laparoscopic versus open adrenalectomy for large pheochromocytoma: a single-center retrospective study. World J Surg Oncol 2019; 17:111.

26. Cherian J, Kothari S, Angelis D, et al. Atypical takotsubo cardiomyopathy: dobutamine-precipitated apical ballooning with left ventricular outflow tract obstruction. Jr Tex Heart Inst J 2008; 35(1):73-5.

27. Silberbauer J, Hong P, Lloyd GW. Takotsubo cardiomyopathy (left ventricular ballooning syndrome) induced during dobutamine stress echocardiography. Eur J Echocardiogr 2008; 9(1):136-8. 


\title{
Катехоламин-индуцированная кардиомиопатия - клинический случай
}

\author{
Людмила Владимирова-Китова ${ }^{1,2}$, Спас Китов ${ }^{2}$, Петар Учиков ${ }^{2,3}$, Георги Павлов ${ }^{2,4}$ \\ ${ }^{1}$ Секция кардиологии, Первая кафедра внутренних болезней, Медицинский университет - Пловдив, Пловдив, Болгария \\ 2 умБАЛ „Св. Георги“, Пловдив, Болгария \\ ${ }^{3}$ Кафедра специализированной хирургии, Факультет медицинь, Медицинский университет - Пловдив, Пловдив, Болгария \\ ${ }^{4}$ Кафедра анестезиологии, неотложной медицинской помощи и интенсивной терапии, Факультет медицинь, Медицинский университет - \\ Пловдив, Пловдив, Болгария
}

Адрес для корреспонденции: Людмила Владимирова-Китова, Секция кардиологии, Первая кафедра внутренних болезней, Медицинский университет - Пловдив, УМБАЛ „Св. Георги“, Пловдив, Болгария; E-mail: kitov@vip.bg; Teл.: +359 888428255

Дата получения: 16 января 2021 Дата приемки: 21 апреля 2021 Дата публикации: 28 февраля 2022

Образец цитирования: Vladimirova-Kitova L, Kitov S, Uchikov P, Pavlov G. Catecholamine-induced cardiomyopathy - a clinical case. Folia Med (Plovdiv) 2022;64(1):156-61. doi: 10.3897/folmed.64.e63215.

\section{Резюме}

У больного 27-ми лет в течение 3 месяцев отмечались эпизодические головные боли и стойкое повышение артериального давления (до 240/120). Клинические, лабораторные и инструментальные данные (приступы тяжелой артериальной гипертензии, повышенный уровень метанефрина в моче и МРТ-обследование,выявившее находку размером 5.1×5.5 см в диаметре, позволили поставить диагноз: фреохромоцитома правого надпочечника. Предоперационные препараты включали альфа-блокаторы, блокаторы кальциевых каналов и плазму. Правый надпочечник полностью удалён забрюшинным доступом. Во время удаления опухоли наблюдалась желудочковая тахикардия с последующей острой сердечной недостаточностью. В первые несколько часов эхокардиография показала снижение ЕФ на 9\% - катехоламин-индуцированная кардиомиопатия. Больному проведена комплексная и адекватная реанимация в реанимационном отделении, которая длилась 20 дней. Наблюдалось медленное, но постепенное увеличение фракции выброса наряду с уменьшением застоя. Для подтверждения нормализации морфологии миокарда использовали магнитно-резонансную томографию. Для подтверждения доброкачественной формы опухоли использовалась немецкая гистологическая лаборатория. В течение следующих трёх месяцев больной находился на стандартной терапии бета-адреноблокаторами, ингибиторами ангиотензинпревращающего фермента и антагонистами минералокортикостероидов. Повышение уровня катехоламинов при удалении крупной феохромоцитомы могло привести к тяжёлым сердечно-сосудистым осложнениям даже при адекватной предоперационной консервативной терапии. Обратимость процесса предполагает необходимость адекватного и своевременного послеоперационного лечения для полного купирования патоморфологических изменений.

\section{Ключевые слова}

катехоламин-индуцированная кардиомиопатия, феохромоцитома, послеоперационные осложнения 